\title{
Evaluation of the Fulfillment of Business Continuity Management System Elements: A Case Study of Clean Water Provision and Services PT. XYZ in Indonesia
}

\section{Adi Gadang Wiratmoko and Zulkifli Djunaidi}

Occupational Health and Safety Department, Faculty of Public Health, Universitas Indonesia, Jl. Margonda Raya, Beji, Pondok Cina, Kota Depok, Jawa Barat 16424, Indonesia

\section{Abstract}

Every business organization is exposed to risks that can disrupt its continuity. Therefore, all organizations need an effective business continuity plan. However, many companies and organizations lack an effective business continuity management system or plan. This case study was conducted on a company that produces and

Corresponding Author: Zulkifli Djunaidi zul@ui.ac.id

Received: 15 May 2018 Accepted: 3 June 2018 Published: 19 June 2018

Publishing services provided by Knowledge $\mathrm{E}$

(c) Adi Gadang Wiratmoko and Zulkifli Djunaidi. This article is distributed under the terms of the Creative Commons

Attribution License, which permits unrestricted use and redistribution provided that the original author and source are credited.

Selection and Peer-review under the responsibility of the ICOHS 2017 Conference Committee. provides clean water services (PT. XYZ) in Indonesia. Many potential risks are posed by internal and external factors, such as disaster events that include fire breakouts, flooding, earthquakes, riots, and chlorine leakage, which may significantly disrupt PT. XYZ's operations and threaten the safety of workers, the environment, and other conditions. The literature related to this study included guideline risk management standards, business continuity management system standards, research reports, theses, journals, and secondary sources. This descriptive study used observations and secondary data. The study examined the fulfillment of a business continuity plan in PT. XYZ, which focused on the assessment and control of potential risks, a business impact analysis, preparedness of the organizational structure, disaster recovery plans, a communication call tree, equipment, and the infrastructure needed during disaster events. The results showed that reliability level of PT. XYZ business continuity management was at a medium level. The results of this study could be used by companies and organizations to manage potential risks appropriately and achieve optimal recovery in cases of disaster or other interruptions to their business.

Keywords: business continuity management system, risk management, business continuity cycle 


\section{Introduction}

In Indonesia, economic development continues to increase. In the reported quarter, the World Bank estimated that Indonesia's GDP would grow by 5.3 percent in 2018. In addition, inflation was estimated to reach 4.3 percent in 2017 [1]. Under these conditions, economic stability and business continuity must be maintained and promoted, which is difficult if the world economy is interrupted by a catastrophe. Emergency situations, such as fires, floods, earthquakes, and other natural and human-made disasters should be prepared for, stabilized, and controlled before they reach crisis proportions [2].

Potential risks that could interfere with business and cause financial or non-financial losses must be managed effectively [3]. In risk management, the process is an integrated part of the organization's management. It is part of the culture and activities of the organization, and it is adapted by using business process organization [4]. Risk management, in addition to good organizational practice, needs to anticipate interruptions in business, such as planning the continuity of the business plan and ensuring that it is comprehensive and reliable [3].

Business continuity management is the process of identifying potential threats and their effects on business operations. In addition, a framework should be developed to ensure the resilience of the organization in order to safeguard the interests of its key stakeholders, its reputation, its brand, and its value-creating activities [5]. The presence of a good business continuity plan (BCP) has the effect of reducing the effects of the disasters on inter-regional development as well as minimizing the risk of other losses. BCP also aims to improve the ability of the organization to recover in the aftermath of a disaster [6].

The PT. XYZ company provides a clean water service. In the case of an interruption in its business operations, PT. XYZ risks financial and non-financial losses. PT. XYZ has several water treatment plants, pipe networks, and the supporting elements required to run its major business activity, which is to produce clean water and distribute it to their customers. Therefore, the aim of this study is to evaluate the business continuity management system and plans in the PT. XYZ company.

\section{Methods}

Descriptive research includes reviewing the relevant literature, conducting interviews with BCP coordinator, and recording direct observations. In the present study, the collected data are analyzed using the guidelines in ISO 31000 and ISO 22301. 
The risk management process based on ISO 31000 begins by establishing the context and then performing the following stages of risk assessment: risk identification, risk analysis, risk evaluation, and risk treatment. Risk management includes communication and consultation as well as performance monitoring and reviewing [4] (Figure 1).

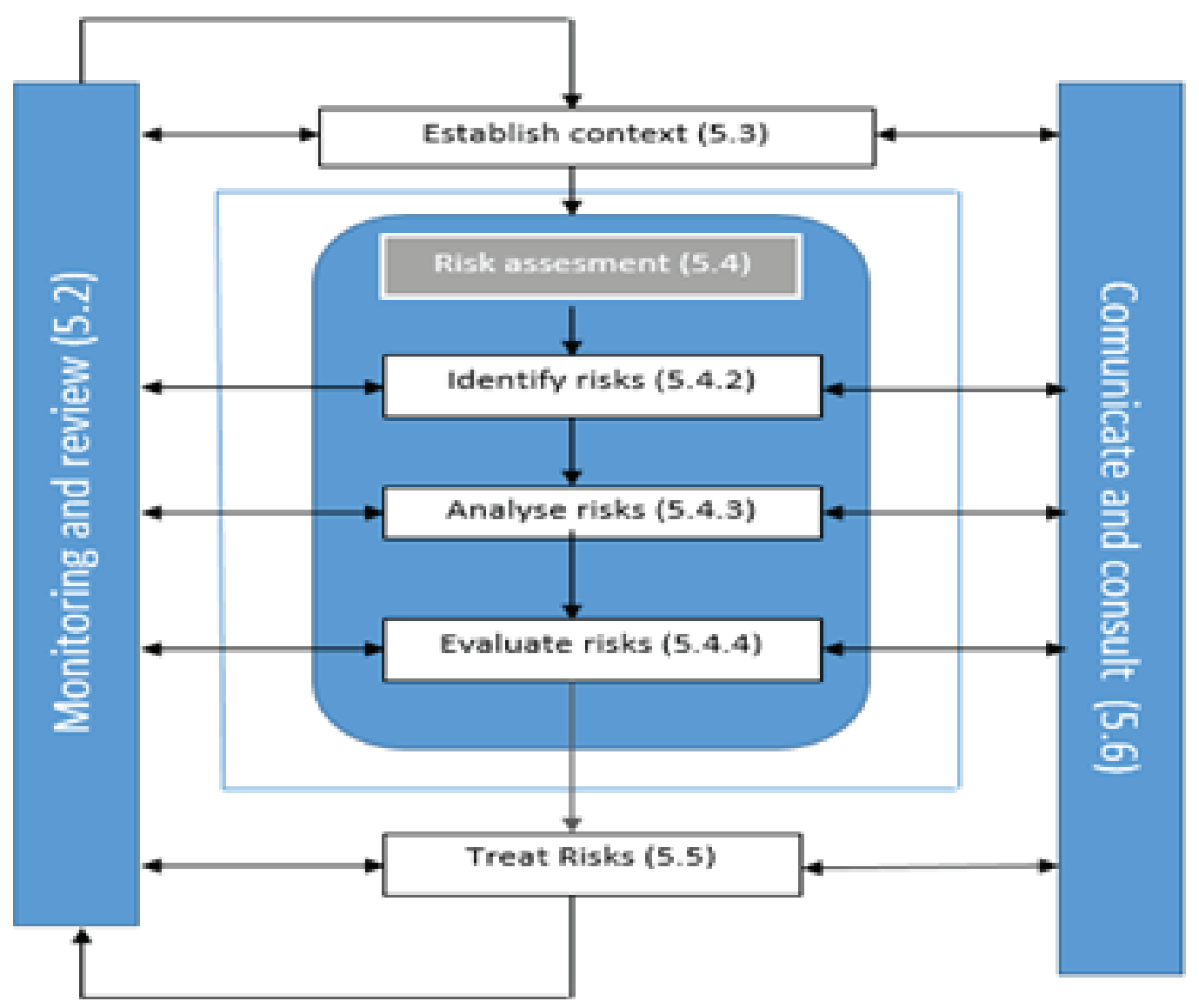

Figure 1: ISO 31000:2009 risk management process.

An important aspect of building a business continuity management system includes the following: policy, people, and management processes relating to policy, such as planning, implementation, operation, performance assessment, management review, improvement [5]. Documentation should provide evidence that can be audited to ensure that the sustainability and management processes are relevant to the business of the company [5]. ISO 22301 (i.e., Plan-Do-Check-Act) follows the standard ISO pattern (Figure 2). 


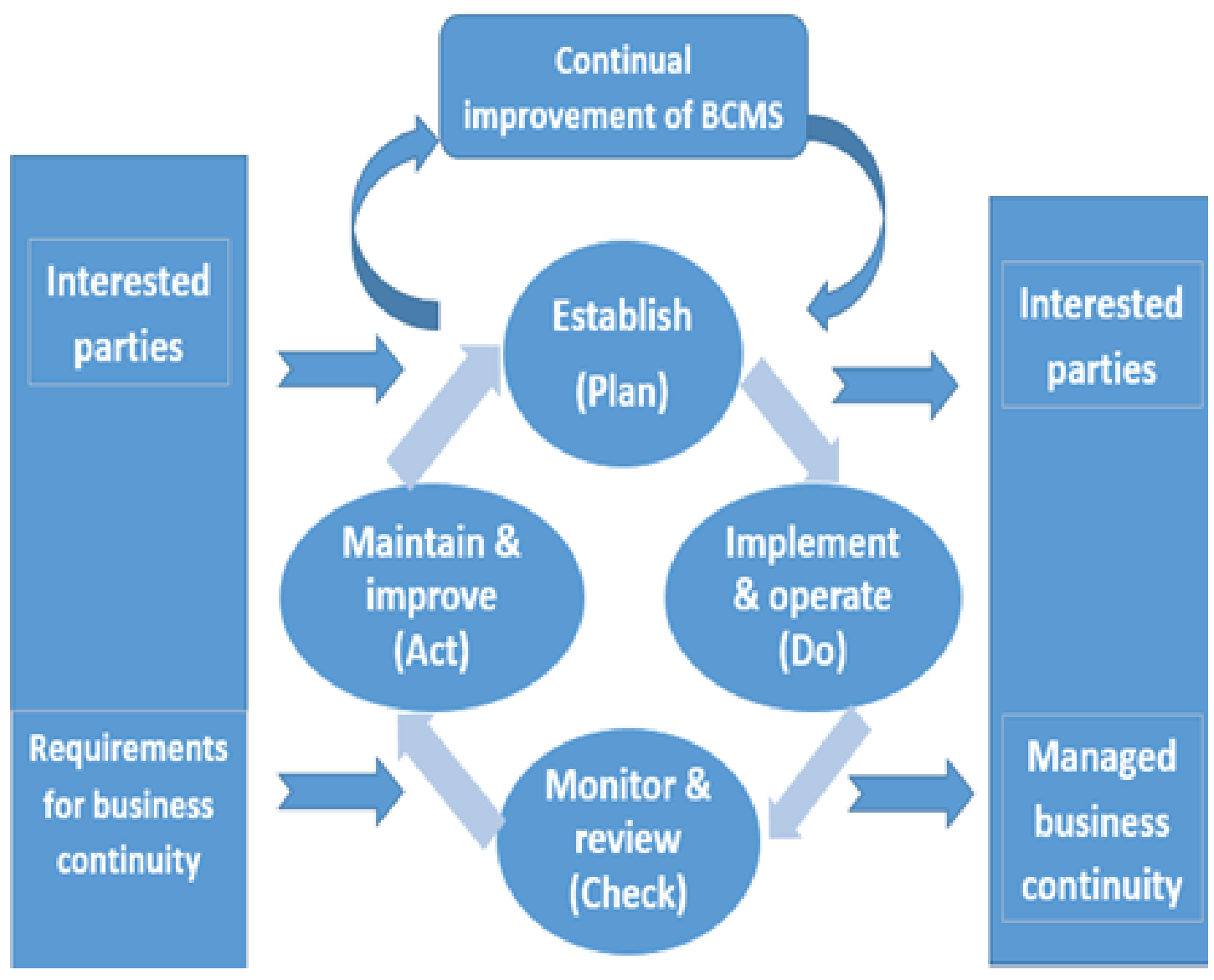

Figure 2: PDCA Model BCMS ISO 22301.

\section{Results}

The BCP includes the measures that must be taken during incidents and natural disasters. The BCP process in PT. XYZ was conducted on 22 essential functions in the contexts of four scenarios of disaster events: fire, earthquake, riot, and chlorine gas leakage, all of which pose significant potential risks to the company's business operations [7]. The preparation of business continuity plan includes risk identification, analysis of the impact on business, and setting up the structure of the organization's BCP (Figure 3).

Which include the following: disaster recovery function (Figure 4);

Disaster management plan (including priority of actions); the communication call tree; equipment including infrastructure; and the estimated cost incurred by the disaster event [7]. A thorough guide has documented and consolidated. PT. XYZ has a control room and an on-call service team that can be reached outside working hours to ensure that every business unit runs normally [7].

After evaluating the BCP documents, reviewing the relevant literature, conducting interviews with $\mathrm{BCP}$ coordinator (Table 1 ). 


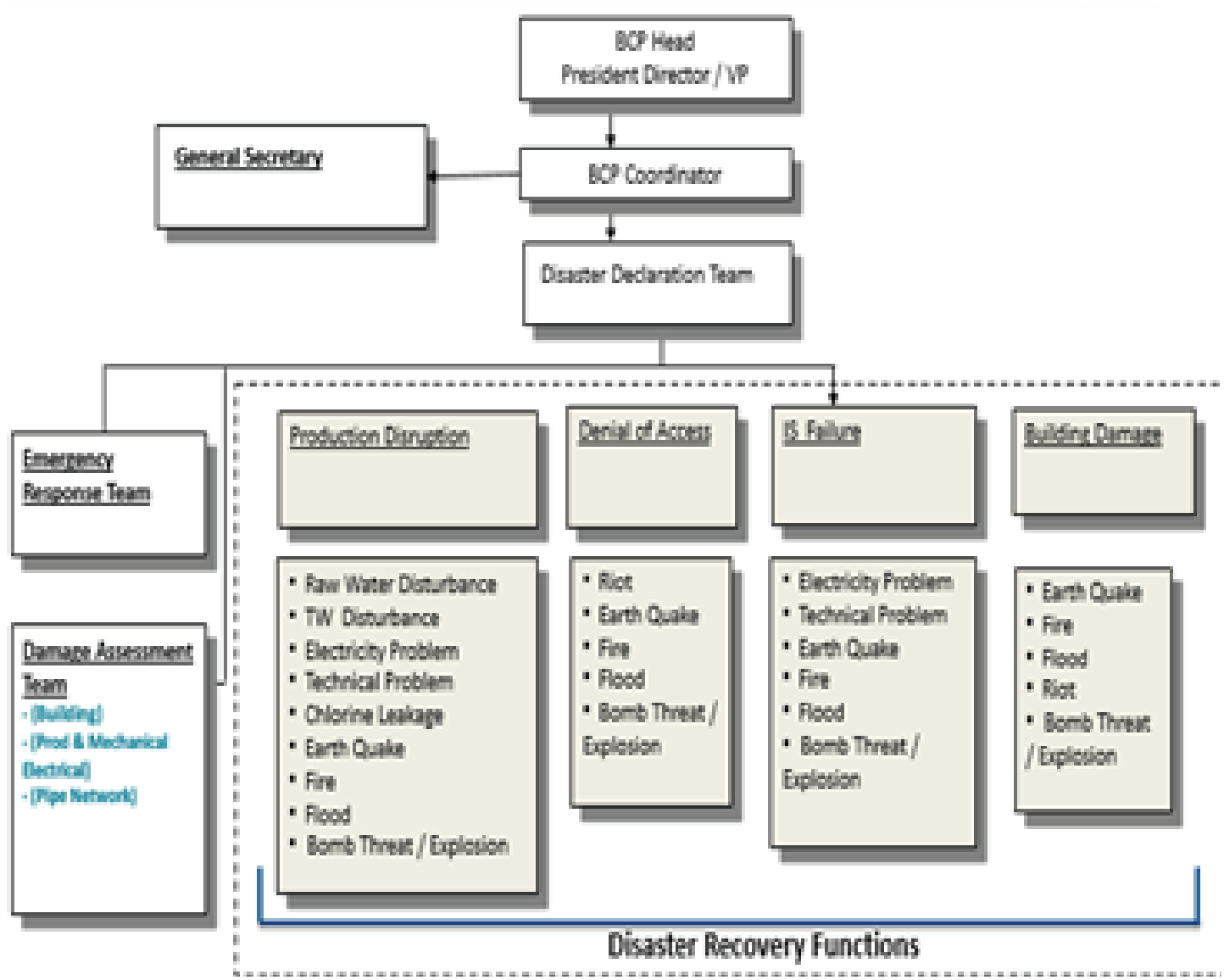

Figure 3: BCP organization PT. XYZ.

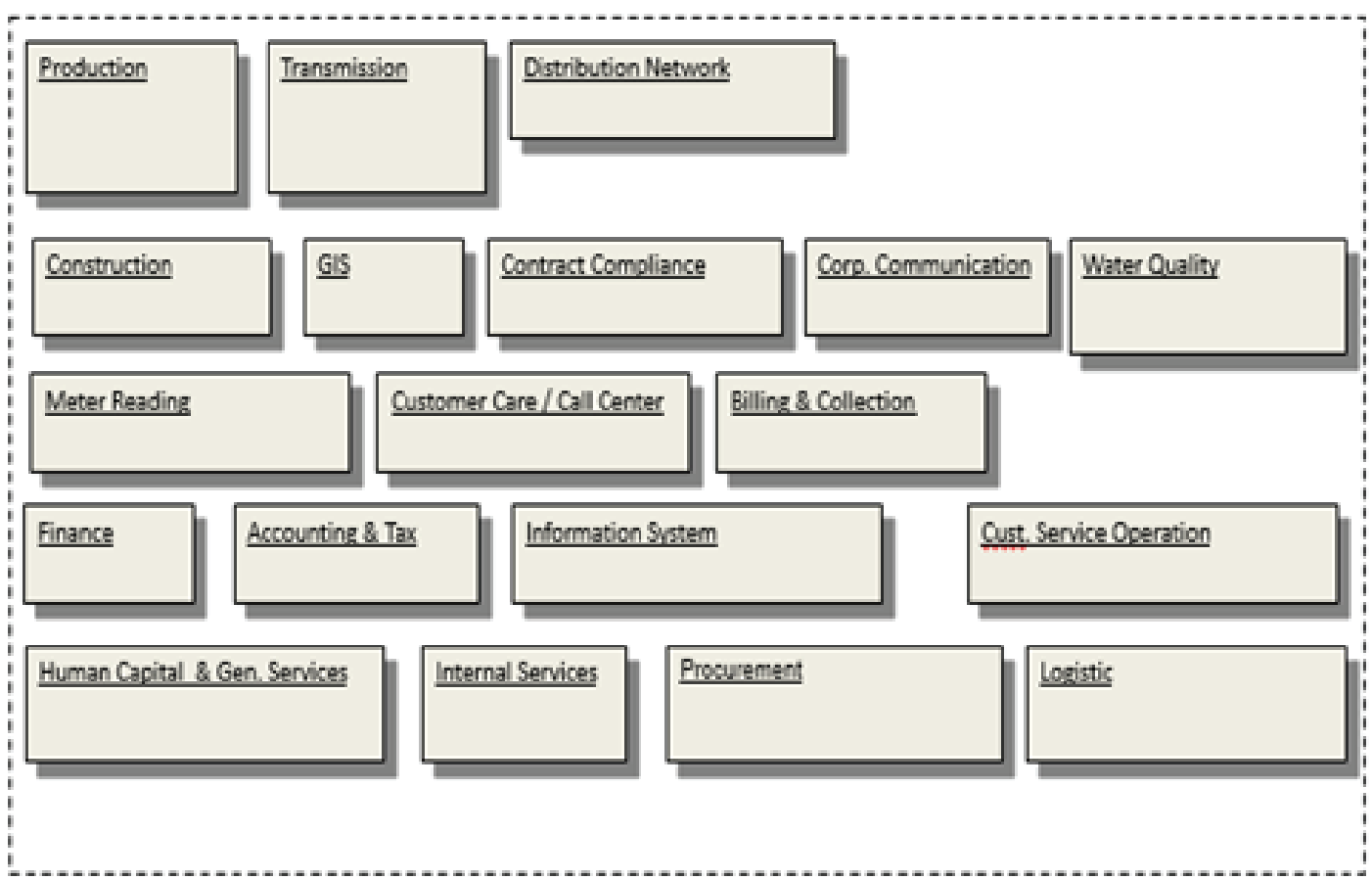

Figure 4: Disaster recovery functions PT. XYZ. 
TABLE 1: The results of the interviews with BCP coordinator.

\section{Questions}

Does PT. XYZ perform risk management in each unit of work?

Has PT. XYZ already conducted a business impact analysis?

Has PT. XYZ compiled a scenario work case?

Does PT. XYZ already have a BCP organization structure?

Has PT. XYZ done emergency preparedness?

Has the emergency response procedure been established?

Has the classification of tiered emergency conditions been determined?

Has the maximum tolerable downtime been determined?

Has PT. XYZ already prepared for recovery?

\section{Answers}

Yes, already done and listed on the HIRA and risk register of each department

Already done based on the results of business impact analysis questionnaire completed by each department

Yes, on critical and major business functions

Already done involving the various functions of the organization

Already formed and equipped with an action plan

Already established

Already determined. However less comprehensive and less commitment in activating the $\mathrm{BCP}$ clause

Maximum tolerable downtime has not been determined because of many external factors and low commitment

Already done through the disaster recovery functions

The company used a checklist based on guidelines that were adopted from clauses in ISO 31000 and ISO 22301 (Table 2).

The results showed that 20 clauses of the 28 clauses in the guidelines were fulfilled and that the dependability of PT. XYZ's BCP was at the medium level.

\section{Discussion}

The management of PT. XYZ has committed to preparing (Plan) a sustainability operational company in the event of a disaster. With regard to the BCP, PT. XYZ already had organization and disaster recovery functions. In PT. XYZ, the BCP functions to involve employees in every unit of work and area of responsibility. With regard to the disaster recovery function, if a disruption happens, the organization can activate this function in in accordance with policy management [7].

In preparing the $\mathrm{BCP}, \mathrm{PT}$. XYZ conducted the risk management process. The risk register of units of work produced an overall picture of the likelihood and severity of major risks to the company. The risk identification in units of work was validated according to those responsible for a unit of work. The BCP function coordinator assisted in evaluating and identifying financial risks (business impact analysis), infrastructure 
risk communication, transport links, marketplace risk, and reputational risk (media relations, SMS broadcasts to consumers). The business impact analysis (BIA) examined risk assessment not only in the process, but also assets and critical information about who became a rating factor risk business identified after determining major risk [7].

In terms of business continuity strategies, PT. XYZ had compiled a worst-case production scenario, which included a case-by-case analysis of the production units in the form of the total amount of fresh water that could be produced according to the PT. XYZ's water treatment plan during a disruption. The worst-case production scenario was compiled to facilitate the determination of the level clause BCP activated [7].

The weaknesses in PT. XYZ's BCP plan included the following: the absence of a risk mitigation update, the absence of the determination of the value of the maximum tolerable period of disruption (MTPD) as well as the absence of recovery point objectives (RPO) and recovery time objectives (RTO). MTPD is the time required for adverse effects to emerge, which might cause a service to become unacceptable [5]. The RTO or destination time is the time expected for the recovery from the effects of the disruption, namely the value of RPO from the time that it was tolerated for the functioning of services [5]. In the case of PT. XYZ, the value of RPO consists of the production and distribution of clean water. The time needed for recovery depends on the criticality of the effects. The higher the priority an activity has in the business process, the less the recovery time [7].

The third value (RTO, RPO, MTPD) has not yet been determined because the commitment and policy management was not considered in determining the amount of the harm to the business. Moreover, PT. XYZ is dependent on external conditions in terms of the raw water available for the production of clean water, electrical sources, and supporting clean water. Because communication is important, the business can recover as soon as possible according to a set and.

In implementing the BCP (Do), PT. XYZ decided to use the strategy of back-up (rescue) and recovery (recovery) to predict disaster risk, determine emergency preparedness and response procedures through the disaster recovery function, develop a crisis communications call tree, and coordinate with external agencies. Recovery by PT. XYZ includes restoring the company's operations as soon as possible. Business is revived by determining the personnel or team responsible and deciding on the procedure used for the recovery of the business. PT. XYZ's BCP was tested by conducting emergency drills. After the drill, the procedure was evaluated to determine weaknesses in order to improve and develop the BCP [7]. 
PT. XYZ's BCP was checked (Check) by implementing socialization and training all the company's officers periodically and then evaluating the results of the training [7]. The objective was to ensure that the business unit personnel understood their responsibilities in the event of a disaster. Monitoring and risk assessments were done and updated according to each function in a unit of work, which are highly important in the risk management processes. With regard to risk monitoring, PT. XYZ should update the risk register and the BIA.

PT. XYZ had conducted (Act) a review of their BCP procedure by making policy changes to it. Internal auditing was conducted once a year to check the completeness of the documents and the readiness of the BCP management [7]. Because the outcome of the internal audit is used as evaluation material, it must be objective.

TABLE 2: Documents and record checklist required by ISO 31000 and ISO 22301.

\begin{tabular}{|c|c|c|c|}
\hline Documents and Record & \multicolumn{2}{|c|}{ ISO 31000 Clause number } & \multirow{2}{*}{$\begin{array}{c}\text { Evidence Found } \\
\text { PT. XYZ } \\
\sqrt{ }\end{array}$} \\
\hline Establish context & 5.3 & & \\
\hline Identify risks & 5.4 .2 & Risk Assessment & $\begin{array}{l}\sqrt{ } \text { (HIRA and Risk } \\
\text { Register })\end{array}$ \\
\hline Analyze risks & $5 \cdot 4 \cdot 3$ & & \\
\hline Evaluate risks & 5.4 .4 & & \\
\hline Monitor and review & 5.2 & & - (not updated) \\
\hline Communicate and consult & 5.6 & & - (not updated) \\
\hline Documents and Record & ISO 223 & 1 Clause number & $\begin{array}{l}\text { Evidence Found } \\
\text { PT. XYZ }\end{array}$ \\
\hline Organizational context & 4.1 & Plan & $\sqrt{ }$ \\
\hline $\begin{array}{l}\text { Identification of regulatory and regulatory } \\
\text { requirements }\end{array}$ & 4.2 .2 & & $\sqrt{ }$ \\
\hline $\begin{array}{l}\text { List of procedures including legal and } \\
\text { regulatory requirements }\end{array}$ & 4.2 .2 & & $\sqrt{ }$ \\
\hline $\begin{array}{l}\text { Scope of business continuity management } \\
\text { and plans }\end{array}$ & $4 \cdot 3$ & & $\sqrt{ }$ \\
\hline Management commitment & 5.2 & & $\begin{array}{c}\text { (Lack of Clausal } \\
\text { Activation BCP } \\
\text { commitment) }\end{array}$ \\
\hline $\begin{array}{l}\text { Established business continuity context } \\
\text { (internal and external) }\end{array}$ & $5 \cdot 3$ & & $\sqrt{ }$ \\
\hline $\begin{array}{l}\text { Business continuity goals and plans to } \\
\text { achieve them }\end{array}$ & 6.2 & & $\sqrt{ }$ \\
\hline Competences of employee BCP function & 7.2 & & $\sqrt{ }$ \\
\hline Awareness & 7.3 & & $\sqrt{ }$ \\
\hline $\begin{array}{l}\text { Communications call tree with external } \\
\text { parties }\end{array}$ & 7.4 & & (Not found) \\
\hline Business impact analysis and risk assessment & 8.2 .1 & Do & $\sqrt{ }$ \\
\hline
\end{tabular}




\begin{tabular}{|c|c|c|}
\hline Documents and Record & ISO 31000 Clause number & $\begin{array}{l}\text { Evidence Found } \\
\text { PT. XYZ }\end{array}$ \\
\hline Outcome of business impact analysis & 8.2 .2 & $\sqrt{ }$ \\
\hline Outcome of risk assessment & 8.2 .3 & $\sqrt{ }$ \\
\hline Business continuity strategy & 8.3 & $\sqrt{ }$ \\
\hline $\begin{array}{l}\text { Establish and Implement business continuity } \\
\text { procedures }\end{array}$ & 8.4 .1 & $\sqrt{ }$ \\
\hline Incident response structure & 8.4 .2 & $\sqrt{ }$ \\
\hline $\begin{array}{l}\text { Decision whether the risks and impacts are } \\
\text { to be communicated externally }\end{array}$ & 8.4 .2 & $\begin{array}{l}\text { (Lack of Clausal } \\
\text { Activation BCP } \\
\text { commitment) }\end{array}$ \\
\hline $\begin{array}{l}\text { Records of important information about the } \\
\text { incident, action taken, and decisions made }\end{array}$ & 8.4 .3 & $\sqrt{ }$ \\
\hline $\begin{array}{l}\text { Procedures for responding to disruptive } \\
\text { incidents }\end{array}$ & 8.4 .4 & $\sqrt{ }$ \\
\hline \multirow[t]{2}{*}{$\begin{array}{l}\text { Procedures of returning business from } \\
\text { disruptive incidents (recovery) }\end{array}$} & 8.4 .5 & $\begin{array}{l}\text { (Business } \\
\text { functions depend } \\
\text { on external } \\
\text { parties) }\end{array}$ \\
\hline & Check & \\
\hline Results of monitoring and evaluation & 9.1 .1 & - \\
\hline Results of post- incident evaluation & 9.1 .2 & $\sqrt{ }$ \\
\hline Results of internal audit & 9.2 & $\sqrt{ }$ \\
\hline Results of management evaluation & 9.3 & $\sqrt{ }$ \\
\hline Results of corrective actions for improvement & Act & - \\
\hline
\end{tabular}

TABLE 3: Category level BCP PT. XYZ against checklist fulfillment ISO 31000 and ISO 22301 clauses.

\begin{tabular}{|l|l|l|l|}
\hline Category & Level & Fulfill of the Guideline & Action \\
\hline Weak & 10 & Minimum 1-16 Clause & Corrections \\
\hline Medium & 6 & Minimum 17-22 Clause & fixed/restoration \\
\hline Strong & 3 & Minimum 23-28 Clause & Maintain than Improve \\
\hline
\end{tabular}

\section{Conclusion}

Based on the ISO 31000 and ISO 22301 standards, the results showed that PT. XYZ'S BCP fulfilled 23 of 31 clauses and was therefore at the medium level. Based on these results, the company needs to take measures to meet the requirements stated in all clauses (Table 1). In particular, the management's commitment needs to be strengthened in order to determine the tiers and the functions of the $\mathrm{BCP}$, particularly the values of the 


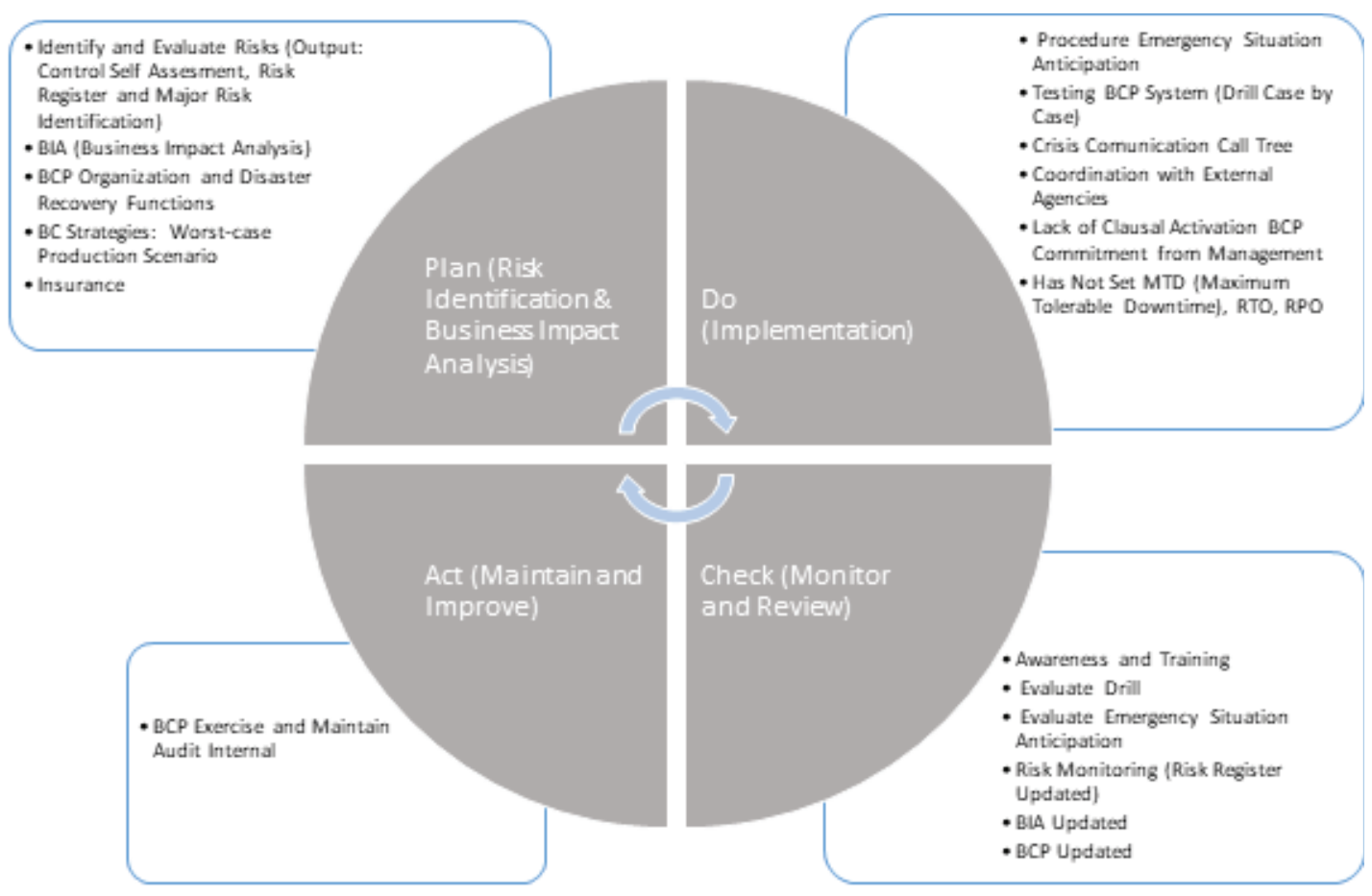

Figure 5: PDCA model PT. XYZ.

MTPD, RTO, and RPO. Determining the third value relies heavily on units outside the company. Therefore, coordination, cooperation, and commitment should be based on contract agreements with external providers. To increase the accuracy of these values, the number of customers in the affected area should be mapped, and a strategy should be developed to handle handling post-disaster disruptions.

The policy statement regarding the responsibilities for the coordination, evaluation, and maintenance of the BCP should also be clear. Emergency training and awareness programs are required for all functions of the $\mathrm{BCP}$, such as the organization and disaster recovery function as well as all employees. The level of training should also support the development and testing of the BIA and BCP.

Evaluations of the effectiveness of BCP programs should be monitored and reported to management, including issues in testing, training, and evaluating the BCP program. If there is a change in a critical business function, then the risk categories must be reviewed so that mitigation, lecturing, losses, and recovery cost can be developed and improved [8].

\section{References}

[1] Retrieved from http://finansial.bisnis.com/read/20170615/9/663024/bank-dunia2017-pertumbuhan-ekonomi-indonesia-diprediksi-52\%-inflasi- $43 \%$ 
[2] Tucker, E. (2015). Emergency management: Preparedness and response, in Business Continuity from Preparedness to Recovery. USA: Elsevier Inc.

[3] Clifton, R. W. (2003). Business continuity planning. Journal of Business Continuity and Emergency Planning, vol. 69, no. 10, pp. 178, 180, 182. Retrieved from http: //www.ncbi.nlm.nih.gov/pubmed/24854728

[4] SO. (2009). ISO 31000: Risk management: Principles and guidelines.

[5] Organización Internacional de Normalización. (2012). ISO 22301:2012 Societal security - Business continuity management systems - Requirements. Retrieved from http://www.iso.org/iso/home/store/catalogue_tc/ catalogue_detail.htm?csnumber $=50038$

[6] Business Continuity Management 2e_ A Crisis Management Approach - Dominic Elliott, Ethné Swartz, Brahim Herbane - Google Buku.

[7] PT XYZ Clean Water Provision and Services PT XYZ in Indonesia - Manajemen Resiko.

[8] Weir, K. and Hensley, J. (January 2015). Evaluating and Improving Your Business Continuity Plan. Northeast Florida IIA Chapter. 